\title{
An Alternative Approach to the Gastroesophageal Reflux Disease: Manual Techniques and Nutrition
}

\author{
Luca Collebrusco $^{1}$, Rita Lombardini ${ }^{2}$, Giovanna Censi ${ }^{3}$ \\ ${ }^{1}$ Rehabilitation Unit-National Health Service of Umbria, Perugia, Italy \\ ${ }^{2}$ Department of Medicine-University of Perugia, Perugia, Italy \\ ${ }^{3}$ INRCA University Polytechnic of Marche, Ancona, Italy \\ Email: luca.collebrusco@unipg.it
}

How to cite this paper: Collebrusco, L., Lombardini, R. and Censi, G. (2017) An Alternative Approach to the Gastroesophageal Reflux Disease: Manual Techniques and Nutrition. Open Journal of Therapy and Rehabilitation, 5, 98-106.

https://doi.org/10.4236/ojtr.2017.53009

Received: July 4, 2017

Accepted: August 7, 2017

Published: August 10, 2017

Copyright $\odot 2017$ by authors and Scientific Research Publishing Inc. This work is licensed under the Creative Commons Attribution International License (CC BY 4.0).

http://creativecommons.org/licenses/by/4.0/

\begin{abstract}
Gastroesophageal reflux disease (GERD) is a chronic digestive disorder that affects a growing number of people in the world and is one of the most common gastric complaints that prompts an individual to consult a doctor. Heartburn and regurgitation are the most predominant esophageal symptoms of GERD, but patients with the disease may also have extra esophageal symptoms, such as epigastric pain, bronchospasm, and chronic cough. All of these symptoms may compromise health-related quality of life with modification of eating habits and sleep pattern that have a great impact on the normal daily. Furthermore, GERD is a multifactorial disease that can be complicated and difficult to treat. Mechanical, chemical, physiopathologic, and functional factors that predispose patients to the disease are still under investigation. A simple treatment plan for manual therapists is presented based on current evidence-based literature; it is designed to reduce symptoms of GERD through somatovisceral approach and the nutrition.
\end{abstract}

\section{Keywords}

Gastroesophageal Reflux Disease, Lower Esophageal Sphincter, Chronic Visceral Pain, Osteopathic Manipulative Treatment, Nutrition

\section{Introduction}

Gastroesophageal reflux disease (GERD) is a chronic disease usually caused by the reflux of acidic gastric and duodenal contents into the distal esophagus. GERD is a common digestive disease with the direct medical costs estimated around $\$ 9.3$ billion annually [1]. 
It has a great medical-social importance, with a high and growing prevalence. It is the cause of various esophageal symptoms 3 - 7 and extra esophageal symptoms [2] [3], having a negative impact on quality of life [4] [5] with reflex on the economy of the society.

GERD results from failure of the barrier mechanism of the lower esophageal sphincter (LES), allowing the distal esophagus to be exposed to gastric juice [1].

This loss of barrier function has been considered largely from a structural perspective, with manometry frequently demonstrating a defective LES in patients with GERD [2] [3].

Pandolfino et al. [6] suggested that the compromised crural diaphragm (CD) function, indicated by diminished inspiratory augmentation of esophagogastric junction (EGJ) pressure found on high-resolution manometry results, is an independent predictor of GERD. They also stated that the radial dimensions or distensibility of the hiatal canal or the thickness and elasticity of the CD itself may be important factors in maintaining diaphragm function.

According to Lossing et al. [7], the viscera are connected to the musculoskeletal system by connective tissue forming functional chains that connect all of the anatomic elements from head to toe.

Nutritional advice, additional and lifestyle modifications are recommended as therapy for GERD.

The present paper defines a simple treatment plan for manual therapists, which is designed to reduce the GERD associated symptoms.

We provide an overview of its management using Osteopathic Manipulative Treatment (OMT), dietary modification and nutritional supplementation, according to the current evidence-based literature.

\section{OMT}

Over a century ago Andrew Taylor Still devised a system of disease prevention and treatment through mechanical manipulation known as OMT. He identified the musculoskeletal system as a key to health, hypothesizing that every illness was the result of an anatomical disorder associated with physiological discord, termed "Somatic Dysfunction" (SD). SD is "impaired or altered function of related components of the somatic framework; skeletal, arthroidal, myofascial and related vascular, lymphatic and neural elements" [8]. It contributes to the effect of organic pathology and is catalogued as a disease of musculoskeletal system (ICD-9, code 739). Primary SD is completely reversible when correctly diagnosed and treated with OMT. Secondary SD also responds to OMT but will recur unless the primary pathology is identified and treated SD is diagnosed by palpation procedures (“A.R.T.T." examination) [9], OMT consists of a range of direct, indirect, combined, fluid and reflex-based manual techniques (Figure 1) that are applied specifically to a joint or non-specifically to a body area [10]. Direct techniques apply thrust, impulse, muscle contraction, fascial loading, or passive range of motion. They engage the restrictive barrier and use an activating force to achieve the tissue response and correct the SD. Indirect, fluid, balancing, 


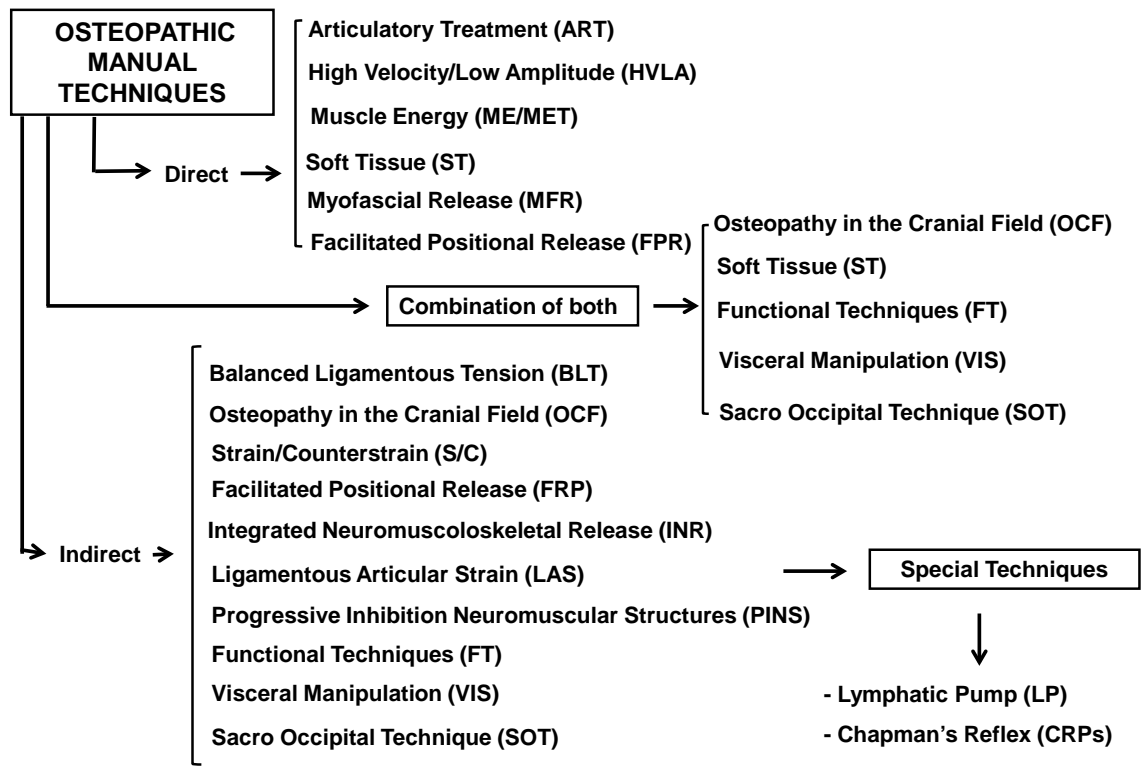

Figure 1. Overview of OMT techniques.

or reflex-based techniques do not engage the restrictive barrier. They use fascial massage, fascial and soft tissue loading or unloading, hydraulic pressures, respiration phases and cranial or postural adjustments [11] [12].

\section{OMT for GERD}

In GERD, OMT focuses on the nervous and circulatory systems, spine, viscera, thoracic and abdominal diaphragm in order to restore homeostatic balance, normalize autonomic activity in the Gastroesophageal junction, promote lymphatic flow and address SD.

The first step assesses the risk factors for esophageal cancer and pattern of signs and symptoms. Safety is paramount. If alarm signals, or "Red Flags" [13] [14] [15], are present the patient should be referred to a physician (Table 1).

Sagittal Plane Symmetry and the Common Compensatory Pattern (CCP) are observed in the postural examination [10] [16]. The therapist then starts palpation using A.R.T.T. diagnostic criteria to search for SD [17]. Attention focuses on sympathetic innervation from the middle thoracic to segments (T5-T10) the collateral sympathetic ganglia (celiac, upper and superior mesenteric).

Treatment of the upper cervical spine and Thoracic, cranial base and general sub-occipital and area releases tension on the vagus nerve, as it passes through the jugular foramen.

Assessment continues with the mid-cervicals (C3, C4, C5), where the phrenic nerve arises to supply the thoracic diaphragm, and visceral manipulative treatment (VIS) with four techniques in reduction: Lower Thoracic Cage Release, Esophageal release, Myofascial Release (MFR) Diaphragm and sphincter normalization by recoil, (Figure 2). In GERD, lymphatic and venous congestion should be treated by the lymphatic pump techniques and stimulation of chapman's reflex points esophagus and stomac (Figure 3). They increase lymph flow and im- 


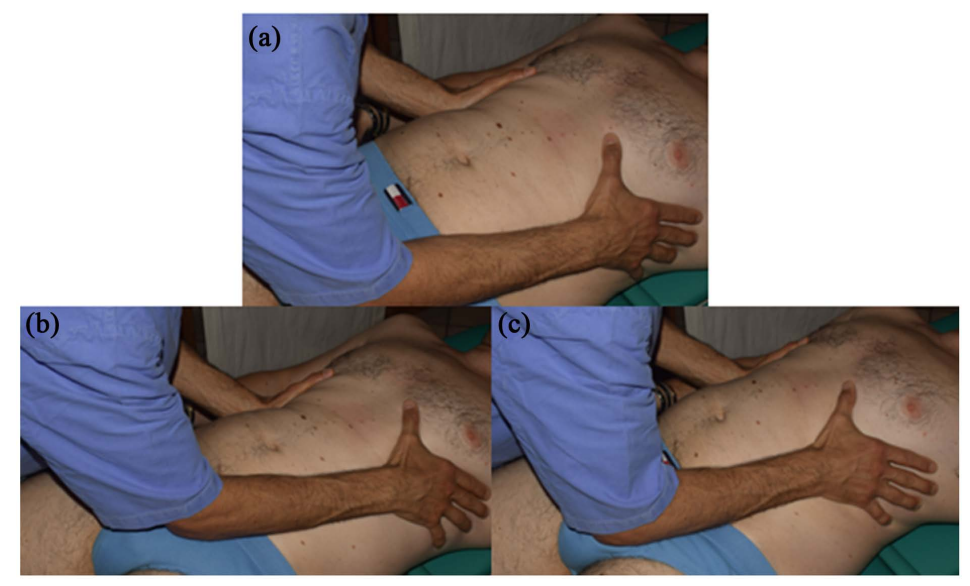

(A)

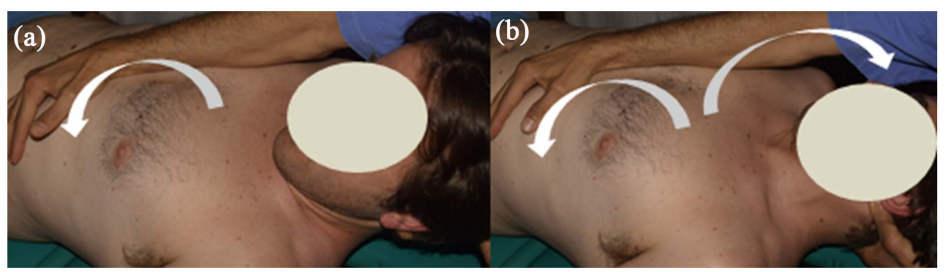

(B)

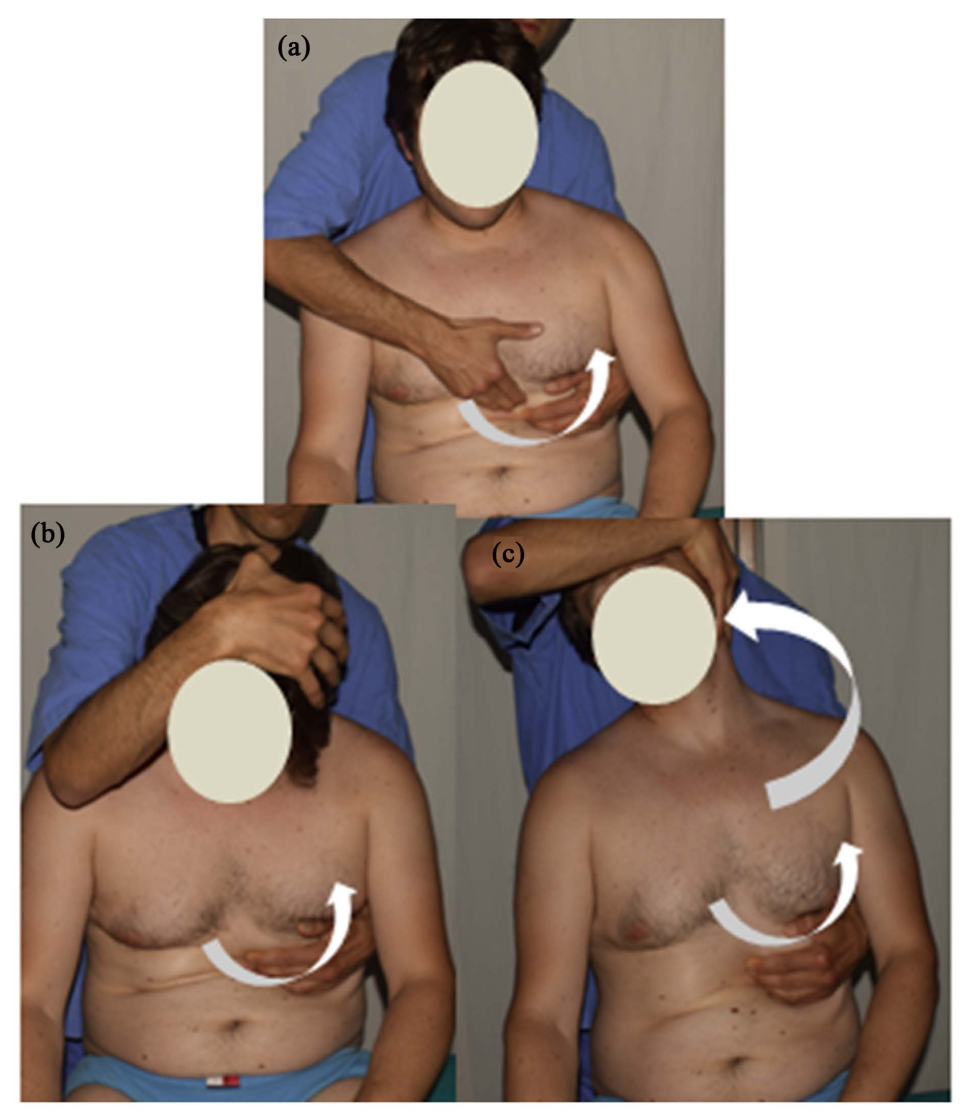

(C)

Figure 2. Manipulation treatment osteopathic for GERD. (A) Lower thoracic cage releas: (a) Start position, (b) and (c) Maneuver; (B) Esophageal releasethe position supine: (a) Start maneuver, (b) Final maneuver; (C) Esophageal release technique the position supine: (a) Position; (b) Start maneuver; (c) Final maneuver. 


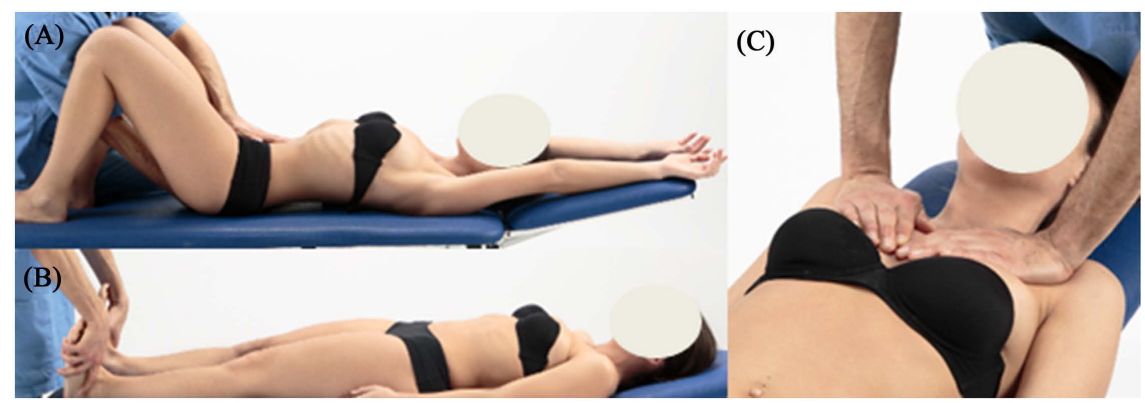

(D)

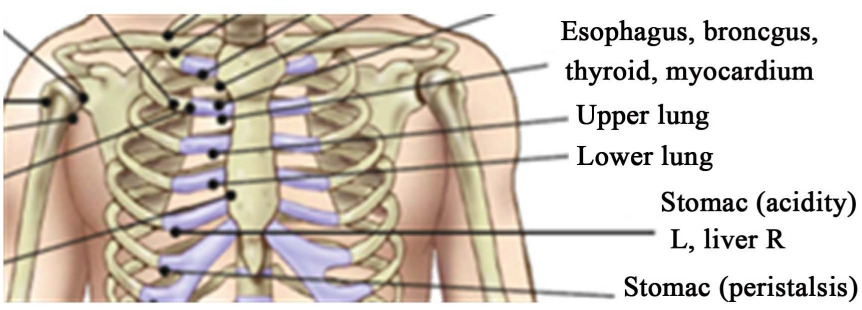

Figure 3. Lymphatic pump techniques and Chapman's Reflex Points (CRP). (A) Abdmonial pump; (B) Pedal pump; (C) Thoracic pump; (D) CRP esophagus and stomac.

Table 1. Risck factor and red flags GERD.

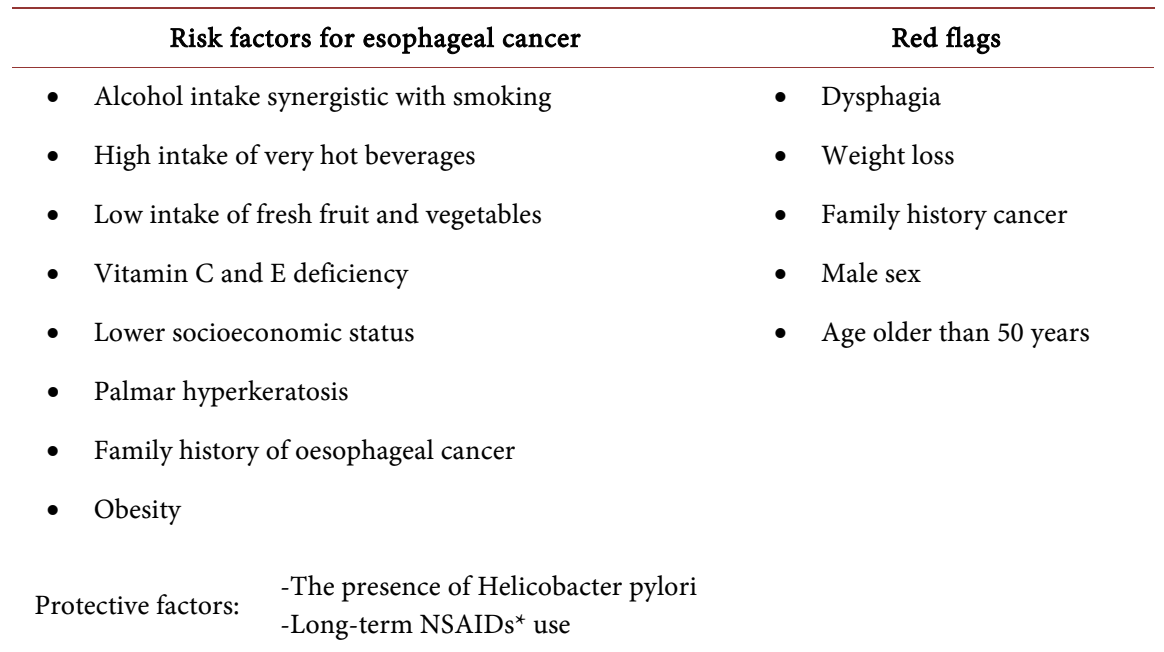

*NSAIDs: Nonsteroidal anti-inflammatory drugs.

prove blood circulation thus facilitating healing and enhancing the efficacy of any medication [10] [12] [18] [19] [20].

\section{Nutrition}

Many lifestyle modifications are recommended as therapy for gastroesophageal reflux disease (Table 2). These include the avoidance of foods that reduce lower esophageal sphincter pressure and thus predispose to reflux, the limiting of exposure to acidic foods that are inherently irritating, and the adoption of behaviors to minimize reflux or heartburn.

Although trials of the clinical efficacy of dietary or behavioral changes are lacking [21], clinical experience suggests that particular patients may benefit 
Table 2. Dietary and lifestyle recommendations for the treatment of GERD.

\begin{tabular}{ll}
\hline Nutritional avoidance & \multicolumn{1}{c}{ Dietary avoidance } \\
\hline & - Food that are acidic or otherwise irritative \\
& - Citrus fruits \\
& - Tomatoes \\
& - Carbons \\
& - Foonated beverages \\
& - Fatty or fried foods \\
& - Coffee, tea, and caffeinated beverages \\
- Chocolate & \\
Nutritional addition & Probiotics
\end{tabular}

*The rationales for proscribed foods and lifestyle modifications are based on clinical experience or, in some instances, small physiological studies showing a relevant effect, such as the reduction of lower esophageal sphincter pressure. These recommendations should be advocated selectively on the basis of the circumstances of a particular patient. BMI denotes body-mass index, which is calculated as the weight in kilograms divided by the square of the height in meters.

from certain measures [22] [23] [24]. For example, patients with sleep disturbance from nighttime heartburn may benefit from elevation of the head of the bed, but that recommendation is probably superfluous for a patient without nighttime symptoms. Weight reduction should routinely be recommended in overweight patients, given the strong association between an increased body-mass index and the likelihood of symptoms [22] [25].

\section{Discussion}

GERD is the most common gastrointestinal diagnosis recorded during visits to outpatient clinics [12]. Although not considered a severe illness [26], it is one of the most common disorders of the gastrointestinal system [27]. It has a great medical-social importance, with a high and growing prevalence. The esophageal symptoms and conditions associated [28] [29] [30] (Table 3) have negative impact on quality of life [31] with reflex on the economy of the society. When standard or surgical medical therapies do not produce the desired outcome or do 
Table 3. Symptoms and conditions associated with GERD.

\begin{tabular}{|c|c|}
\hline $\begin{array}{l}\text { Esophageal } \\
\text { Syndromes }\end{array}$ & $\begin{array}{l}\text { Symptoms with or without esophageal injury } \\
\text { - Common symptoms: heartburn, regurgitation, dysphagia, chest pain } \\
\text { - Less common symptoms: odynophagia (pain with swallowing), } \\
\text { water brash (excessive salivation prompted by acid reflux), } \\
\text { subxiphoid pain, nausea. }\end{array}$ \\
\hline $\begin{array}{l}\text { Extraesophageal } \\
\text { Syndromes }\end{array}$ & $\begin{array}{l}\text { Good evidence only when accompanied by an esophageal syndrome } \\
\text { - Chronic cough } \\
\text { - Laryngitis (hoarseness, throat clearing), reflux usually a cofactor along } \\
\text { with excessive use of the voice, environmental irritants, and smoking } \\
\text { - Asthma (reflux as cofactor leading to poorly, controlled disease) } \\
\text { - Erosion of dental enamel } \\
\quad \text { Association not causation established with the GERD } \\
\text { - Pharyngitis } \\
\text { - Sinusitis } \\
\text { - Recurrent Otitis media }\end{array}$ \\
\hline
\end{tabular}

result in adverse effects, patients may turn to complementary or alternative treatments. In the United States, the overall expenditure for complementary and alternative medicine is in the tens of billions of dollars per year [32]. Alternative methods of treatments are being investigated to avoid long periods of drug treatment or surgical procedures. Osteopathic manipulative treatments (OMT), which are considered by some to be a complementary or alternative medicine, are based on concepts and unique approaches that enable the self-healing and self-regulating process within the body [33]. Generally, 1 to 3 treatment sessions will reveal whether an osteopathic approach is helpful and cost effective [7]. Other well controlled studies evaluating new therapeutic options, to be used either alone or in association with well-established methods of treatment for GERD, are necessary [34]. The OMT provides the patient with relaxation, normalized autonomic control mechanisms, congestion and symptom relief, and better control over his/her reactions to stress [12].

\section{Conclusion}

Therapists now need to take a more holistic view of patients with GERD and provide a more comprehensive treatment model. Combining OMT with appropriate nutrition appears to be an optimal approach and might represent a promising strategy. Although this therapeutic plan may not be ideal for everyone, the majority of patients could well benefit from its use. The positive effect of the OMT program on quality of life shows that visceral applications can be useful [35]. The combination of the therapeutic model OMT and Nutrition described could represent both improvements in quality of life that reduction a health care costs.

\section{References}

[1] Sandler, R.S., Everhart, J.E., Donowitz, M., et al. (2002) The Burden of Selected Digestive Diseases in the United States. Journal of Gastroenterology, 122, 1500-1511. 
https://doi.org/10.1053/gast.2002.32978

[2] Fisher, R.S., Malmud, L.S., Roberts, G.S. and Lobis, I.F. (1977) The Lower Esophageal Sphincter as a Barrier to Gastroesophageal Reflux. Gastroenterology, 72, 19-22.

[3] Johnsson, F., Joelsson, B. and Gudmundsson, K. (1989) Determinants of Gastrooesophageal Reflux and Their Inter-Relationships. British Journal of Surgery, 76, 241. https://doi.org/10.1002/bjs.1800760309

[4] Vakil, N.B., Halling, K., Becher, A. and Ryden, A. (2013) Systematic Review of Patient-Reported Outcome Instruments for Gastroesophageal Reflux Disease Symptoms. European Journal of Gastroenterology \& Hepatology, 25, 2-14. https://doi.org/10.1097/MEG.0b013e328358bf74

[5] Komarchuk, V.V. (2012) Evaluation of Quality of Life of Patients with Complicated Forms of Ulcer in Combination with Reflux Disease. Klinicheskaia khirurgiia, 10, 62-64. (In Russian)

[6] Pandolfino, J.E., Kim, H., Ghosh, S.K., Clarke, J.O., Zhang, Q. and Kahrilas, P.J. (2007) High-Resolution Manometry of the EGJ: An Analysis of Crural Diaphragm Function in GERD. The American Journal of Gastroenterology, 102, 1056-1063.

[7] Lossing, K. (2011) Visceral Manipulation. In: Chila, A.G., Ed., Foundations of Osteopathic Medicine, 3rd Edition, Lippincott Williams \& Wilkins, Baltimore, 845849.

[8] Glover, J.C. (2006) Educational Council on Osteopathic Principles. Glossary of Osteopathic Terminology. American Association of Colleges of Osteopathic Medicine, Chicago. http://www.do-online.org/pdf/sir collegegloss.pdf

[9] Chaitow, L. (2012) The ARTT of Palpation? Journal of Bodywork \& Movement Therapies, 16, 129-131.

[10] DiGiovanna, E.L. (2005) Goals, Classifications, and Models of Osteopathic Manipulation. In: Di Giovanna, E.L., Schiowitz, S. and Dowling, D.J., Eds., An Osteopathic Approach to Diagnosis and Treatment, 3rd Edition, Lippincott Williams \& Wilkins, 77-79.

[11] SOPE. The Scope of Osteopathic Practice in Europe. European Federation of Osteopaths Editors, Brussels, Paris Draft.

[12] Collebrusco, L. and Lombardini, R. (2013) Osteopathic Manipulative Treatment and Nutrition: An Alternative Approach to the Irritable Bowel Syndrome. Health, 5, 87-93. https://doi.org/10.4236/health.2013.56A2013

[13] APTA (2011) Today's Physical Therapist: A Comprehensive Review of a 21st-Century Health Care Profession. American Physical Therapy Association.

[14] Goodman, C.C. and Snyder, T.K. (2007) Differential Diagnosis for Physical Therapists. Screening for Referral. 4th Edition, Elsevier, Mosby Saunders, 393-395.

[15] Nicholas Williams MB BS, FRACS, KAI BROWN MB BS, BScMed (Hons) (2015) Oesophageal Cancer Don't Miss the Early Signs. Medicine Today, 16, 24-33.

[16] DeStefano, L. (2011) Greenman's Principles of Manual Medicine. 4th Edition, Lippincott Williams \& Wilkins, Philadelphia.

[17] Maitland, G.D., Hengeveld, E., English, K. and Banks, K. (2005) Maitland's Vertebral Manipulation. 7th Edition, Butterworth Heinemann, Oxford.

[18] Capobianco, J.D. (2005) Chapman's Reflex Points. In: DiGiovanna, E.L., Schiowitz, S. and Dowling, D.J., Eds., An Osteopathic Approach to Diagnosis and Treatment, 3rd Edition, Lippincott Williams \& Wilkins, Philadelphia, 113-117.

[19] Hodge, L.M. and Downey, H.F. (2011) Lymphatic Pump Treatment Enhances the Lymphatic and Immune Systems. Experimental Biology and Medicine, 236, 1109 1115. https://doi.org/10.1258/ebm.2011.011057 
[20] Lombardini, R. and Collebrusco, L. (2016) Osteopathy and Nutrition for Managing the Irritable Bowel Syndrome-Brief and Useful Guide. Universitas Studiorum, Mantova.

[21] Newberry, C. and Lynch, K. (2017) Can We Use Diet to Effectively Treat Esophageal Disease? A Review of the Current Literature. Current Gastroenterology Reports, 19, 38. https://doi.org/10.1007/s11894-017-0578-5

[22] Kahrilas, P.J., Shaheen, N.J., Vaezi, M., et al. (2008) AGAI Medical Position Statement: Management of Gastroesophageal Reflux Disease. Gastroenterology, 135, 1383-1391. https://doi.org/10.1053/j.gastro.2008.08.045

[23] Peter, J. and Kahrilas, M.D. (2008) Gastroesophageal Reflux Disease. The New England Journal of Medicine, 359, 1700-1707. https://doi.org/10.1056/NEJMcp0804684

[24] Kaltenbach, T., Crockett, S. and Gerson, L.B. (2006) Are Lifestyle Measures Effective in Patients with Gastroesophageal Reflux Disease? An Evidence-Based Approach. Archives of Internal Medicine, 166, 965-971. https://doi.org/10.1001/archinte.166.9.965

[25] Armstrong, D., Marshall, J.K., Chiba, N., et al. (2005) Canadian Consensus Conference on the Management of Gastroesophageal Reflux Disease in Adults-Update 2004. Canadian Journal of Gastroenterology, 19, 15-35. https://doi.org/10.1155/2005/836030

[26] Ducrotté, P. and Liker, H.R. (2007) How Do People with Gastrooesophageal Reflux Disease Perceive Their Disease? Results of a Multinational Survey. Current Medical Research and Opinion, 23, 2857-2865. https://doi.org/10.1185/030079907X233412

[27] Cibor, D., Cieko-Michalska, I., Szulewski, P., et al. (2007) Etiopathogenetic Factors of Esophagitis in Patients with Gastroesophageal Reflux Disease. Przeglad Lekarski, 64, 1-4.

[28] Struch, F., Schwahn, C., Wallaschofski, H., et al. (2008) Self-Reported Halitosis and Gastro-Esophageal Reflux Disease in the General Population. Journal of General Internal Medicine, 23, 260-266. https://doi.org/10.1007/s11606-007-0486-8

[29] Moraes-Filho, J.P.P., Navarro-Rodriguez, T., Barbuti, R., et al. (2010) Guidelines for the Diagnosis and Management of Gastroesophageal Reflux Disease: An EvidenceBased Consensus. Arquivos De Gastroenterologia, 47, 99-115. https://doi.org/10.1590/S0004-28032010000100017

[30] Irvine, E.J. (2004) Quality of Life Assessment in Gastro-Oesophageal Reflux Disease. Gut, 53, 35-39. https://doi.org/10.1136/gut.2003.034314

[31] Quigley, E.M. and Hungin, A.P. (2005) Review Article: Quality-of-Life Issues in Gastro-Oesophageal Reflux Disease. Alimentary Pharmacology \& Therapeutics, 22, 41-47. https://doi.org/10.1111/j.1365-2036.2005.02608.x

[32] Michelfelder, A.J., Lee, K.C. and Bading, E.M. (2010) Integrative Medicine and Gastrointestinal Disease. Primary Care, 37, 255-267.

[33] Posadzki, P. and Ernst, E. (2011) Osteopathy for Musculoskeletal Pain Patients: A Systematic Review of Randomized Controlled Trials. Clinical Rheumatology, 30, 285-291. https://doi.org/10.1007/s10067-010-1600-6

[34] Shaheen, N.J., Hansen, R.A., Morgan, D.R., et al. (2006) The Burden of Gastrointestinal and Liver Diseases, 2006. The American Journal of Gastroenterology, 101, 2128-2138. https://doi.org/10.1111/j.1572-0241.2006.00723.x

[35] Tamer, S., Öz, M. and Ülger, Ö. (2017) The Effect of Visceral Osteopathic Manual Therapy Applications on Pain, Quality of Life and Function in Patients with Chronic Nonspecific Low Back Pain. Journal of Back and Musculoskeletal Rehabilitation, 30, 419-425. https://doi.org/10.3233/BMR-150424 
Submit or recommend next manuscript to SCIRP and we will provide best service for you:

Accepting pre-submission inquiries through Email, Facebook, LinkedIn, Twitter, etc. A wide selection of journals (inclusive of 9 subjects, more than 200 journals)

Providing 24-hour high-quality service

User-friendly online submission system

Fair and swift peer-review system

Efficient typesetting and proofreading procedure

Display of the result of downloads and visits, as well as the number of cited articles Maximum dissemination of your research work

Submit your manuscript at: http://papersubmission.scirp.org/

Or contact ojtr@scirp.org 